\title{
Flowering acceleration in native Brazilian tree species for genetic conservation and breeding
}

\author{
Gleidson Guilherme Caldas Mendes ${ }^{1 \S}$, Gleison Augusto dos Santos ${ }^{1}$, Marcos Deon \\ Vilela de Resende², Sebastião Venâncio Martins'1, Genaina Aparecida de Souza', \\ Andrei Caíque Pires Nunes ${ }^{3}$, Thales Guilherme Vaz Martins'
}

Mendes G.G.C., Santos G.A., Resende M.D.V., Martins S.V., Souza G.A., Pires Nunes A.C., Martins T.G.V., 2020. Flowering acceleration in native Brazilian tree species for genetic conservation and breeding. Ann. For. Res. 63(1):39-52.

Abstract. Grafting and growth retardants are commonly used in breeding programs to stimulate flower production. However, little is known about their effects on Brazilian tree species. The aim of this study was to investigate the vegetative and reproductive development of grafted tree seedlings treated with paclobutrazol (PBZ) and grown under greenhouse or outdoor conditions. Potted seedlings of Jacaranda mimosifolia, Handroanthus heptaphyllus, Swietenia macrophylla, Schinus terebinthifolius, Cariniana legalis, and Hymenaea courbaril were evaluated. Shoot number, length, and circumference as well as flower and fruit numbers were determined at 50 and 90 days after PBZ application. Data were subjected to analysis of variance, and means were compared by Tukey's test $(P \leq 0.05)$. Growing conditions influenced the vegetative parameters of seedlings, especially after 90 days. J. mimosifolia and S. terebinthifolius responded positively to flowering induction, and their fruit and flower numbers differed between growing environments. Potted grafts of the six native tree species were successfully grown. Grafting and PBZ application induced early flowering in J. mimosifolia and S. terebinthifolius.

Keywords: clonal seed orchard,early flowering, greenhouse, plant breeding

Authors. ${ }^{1}$ Departamento de Engenharia Florestal, Universidade Federal de Viçosa, 36570-900, Viçosa, Minas Gerais, Brazil | ${ }^{2}$ Empresa Brasileira de Pesquisa Agropecuária-Embrapa Café, Viçosa, 36570-900, Viçosa, Minas Gerais, Brazil $\mid{ }^{3}$ Centro de Formação em Ciências Agroforestais, Universidade Federal do Sul da Bahia, 45613-204, Itabuna, Bahia, Brazil

§ Corresponding author: Gleidson Guilherme Caldas Mendes (gmendesflorestal@, gmail.com)

Manuscript received January 21, 2020; revised March 3, 2020; accepted March 11, 2020; online first March 16, 2020. 


\section{Introduction}

Plant breeding is an important tool that allows crossing diverse and superior genotypes to obtain heterotic offspring (Horsley et al. 2010). Seed orchards apply many breeding methods, but losses in productivity may arise from inbreeding, self-fertilization (Moran and Bell 1983, Potts et al. 1987), and external pollen contamination, especially when systems are established near other forests (Potts et al. 2008). Therefore, it is important to apply pollination control strategies in seedling seed orchards and clonal seed orchards.

Hybridization is one of the fastest and most efficient ways to enhance genetic gains in forest species (Dickinson et al. 2010, Randall et al. 2015). Many studies have been carried out with Eucalyptus (Assis et al. 2005, Horsley et al. 2010), Corymbia (Dickinson et al. 2010), and Hevea brasiliensis (Hamzah et al. 2002), resulting in increased productivity in forest-based industries (Assis \& Mafia 2007). Genetic improvement programs for native forest species, however, are still incipient.

Growing seedlings in pots, in combination with adequate pollination techniques, eliminates the need to isolate individual flowers; instead, whole plants can be isolated (Assis et al. 2005). This strategy reduces the risk of pollen contamination, facilitates disease and pest management, shortens the time to flowering, and allows large-scale controlled crossings and propagation of high-quality full-sib families, a task previously considered technically and economically unfeasible (Silva et al. 2012). Some crucial aspects should be considered when planning indoor or outdoor seed orchards: parent selection, vegetative propagation techniques, flowering induction methods, pollen management (collection, processing, and storage), and pollination (Silva et al. 2012).

Grafting and growth regulators can be used to induce early flowering in plants (Martínez-Fuentes et al. 2013, Gardner et al. 2016,
Zhang et al. 2016, Soumya et al. 2017, Bindu et al. 2018). Paclobutrazol (PBZ) [(2RS,3RS)1-(4-chlorophenyl)-4,4-dimethyl-2-(1,2,4-triazol-1-yl)-pentan-3-ol] is a triazole fungicide with growth regulatory properties (Soumya et al. 2017). It has been shown to reduce growth (Hasan \& Reid 1995), increase flowering (Gardner et al. 2016), and shorten generation cycles (Wei et al. 2018). PBZ acts by inhibiting the synthesis of gibberellins (GAs), a family of growth hormones (Kishore et al. 2015). Mangifera indica seedlings treated with PBZ produced higher amounts of phenolic and ascorbic acids (Srilatha et al. 2016,Bindu et al. 2018), important compounds for induction of flowering (Barth et al. 2006, Srilatha et al. 2016).

The target tree species of the study (Jacaranda mimosifolia D. Don, Handroanthus heptaphyllus (Vell.) Mattos, Swietenia macrophylla King, Schinus terebinthifoliusRaddi, Cariniana estrellensis (Raddi) Kuntze, Poincianellapluviosa (DC.) LP Queiros and Hymenaea courbaril L.) are widely distributed in Brazil and have great relevance in several segments, such as: in the recovering of degraded ecosystems, in the enrichment of forests, in urban landscaping, in the biomonitoring and phytoremediation of areas with heavy metals and in the production of food, cosmetics and pharmaceutical products (Silva et al. 2010, Veggi et al. 2014, Ma et al. 2018, Oliveira et al. 2018, Balestrin et al. 2019, Costa et al. 2019, Domingos et al. 2019, Souza et al. 2019, Farias et al. 2020, Lisboa et al. 2020).

The aim of this study was to evaluate the vegetative and reproductive development of grafted Brazilian tree seedlings treated with PBZ and grown under greenhouse or outdoor conditions.

\section{Materials and methods}

\section{Study site}

The experiment was conducted in Viçosa, 
Minas Gerais, Brazil, from June to September 2018. Viçosa is located in the Zona da Mata mesoregion of Minas Gerais $\left(20^{\circ} 45^{\prime} \mathrm{S}\right.$ $42^{\circ} 51^{\prime} \mathrm{W}, 652 \mathrm{~m}$ above sea level) and has a moderate humid subtropical climate $(\mathrm{Cwb})$, according to the Köppen classification, with an average annual rainfall of 1,341 $\mathrm{mm}$ and relative humidity of $80 \%$. The annual average, maximum, and minimum temperatures are $22.31,28.2$, and $16.4^{\circ} \mathrm{C}$, respectively.

\section{Plants and growing conditions}

The rootstocks of $J$. mimosifolia, H.heptaphyllus, $S$, macrophylla, $S$. terebinthifolius, $C$. estrellensis, $P$. pluviosa and $H$. courbaril were produced from seeds in $5 \mathrm{~L}$ bags, which were watered daily. Fertilization was performed using $10 \mathrm{~g}$ of 21-00-21 (NPK) slow release fertilizer (Polyblen ${ }^{\circledR}$, Compass Minerals, São Paulo, Brazil) every 90 days. At the time of grafting, the seedlings were 1 year old, about $45 \mathrm{~cm}$ high and with $4 \mathrm{~cm}$ in circumference of the basis of the plant.

The grafts used were collected from adult branches with a tendency to orthotropic growth, containing 20 to $30 \mathrm{~cm}$ in length of mother trees in the field, placed in a thermal box containing gel ice, to avoid dehydration.

The rootstocks were prepared by cutting the tip of the yolk above the first node, making a longitudinal $\mathrm{V}$-shaped cut of about $3 \mathrm{~cm}$ and preserving the lateral branches for a photosynthetic activity. The grafts were excised in the form of a wedge (Figure 1a) and inserted into the rootstock. (Figure 1b). A junction was selected with selection and wrapping with parafilm to avoid water loss and keep the exchange tissues in close contact (Figure 1c). The grafts were performed by a single experienced graft and, weekly, new shoots were removed from the stock to avoid competition with the young ones.

Up to 90 days after grafting, the seedlings were treated with $2.0 \mathrm{ml}$ of paclobutrazol (PBZ) diluted in $250 \mathrm{ml}$ of water $(0.5 \mathrm{~g}$ of active ingredient). Five days after applying the
PBZ, the seedlings were transferred to $20 \mathrm{~L}$ pots, completing the volume of the container with substrate without product, so that part of the roots is in contact with the PBZ and part without contact with the product to avoid toxicity. Fertilization was carried out with $40 \mathrm{~g}$ of Polyblen ${ }^{\circledR}$ 21-00-21 (NPK). As grafted seedlings, they were grown in a greenhouse or outdoors.

\section{Climate}

Greenhouse temperatures ranged from 16.31 ${ }^{\circ} \mathrm{C}$ to $43.77{ }^{\circ} \mathrm{C}$, with an average humidity of $50 \%$. Outdoor temperatures ranged from 15.19 ${ }^{\circ} \mathrm{C}$ to $35.68{ }^{\circ} \mathrm{C}$, with an average humidity of $65 \%$. Total precipitation in outdoor environment during the study months was $158.4 \mathrm{~mm}$.

\section{Data analysis}

The experiment was conducted in a randomized block design and factorial arrangement, containing two factors called orchard type (indoor and outdoor) and species (with six species). Totaled 12 treatments with 15 repetition. Vegetative parameters (shoot number, length, and circumference) and reproductive parameters (flower and fruit number) were evaluated at 50 and 90 days after PBZ application.

Vegetative data were subjected to analysis of variance (ANOVA). When significant differences were found, means were compared by Tukey's test $(P \leq 0.05)$ using Genes (Cruz 2013). Flowering and fruiting data were not normally distributed and were therefore analyzed by descriptive statistics. Statistical analyzes were performed using RBio software (Bhering 2017).

\section{Results}

\section{Vegetative parameters}

The interaction effects of tree species and growing environment were significant $(P \leq$ 
0.05) for shoot number at 50 days after PBZ application. At 90 days after PBZ application, the interaction had a significant effect $(P$ $\leq 0.01$ ) on shoot number and circumference. Shoot length varied significantly between environments and tree species. These data are presented separately in tables and figures.

At 50 days after PBZ application, the shoot number, length, and circumference of greenhouse plants were significantly higher than those of outdoor plants (Table 1). At 50 days after PBZ application, C. legalis had the largest shoot length $(55.78 \mathrm{~cm})$ and $S$. terebinthifolius the second largest (Fig. 2A). J. mimosifolia $(0.95 \mathrm{~cm})$ and $S$. macrophylla $(0.94 \mathrm{~cm})$ had the largest shoot circumference (Fig. 2B).

Plant species had a significant effect on shoot number, regardless of the growing environment (Table 1). Under greenhouse conditions, C. legalis had the largest number of shoots (Fig. 3A), and, under outdoor conditions, $S$. terebinthifolius had the largest number (Fig. 3B).

At 90 days after PBZ application, the mean shoot length (Fig. 4A) and sprouts number (Fig. 4B), differed significantly among plants grown in the greenhouse and plants grown out-

Table 1 Mean shoot number, length, and circumference of grafted seedlings grown under greenhouse or outdoor conditions for 50 days after paclobutrazol application

\begin{tabular}{lll}
\hline Parameter & Greenhouse & Outdoors \\
\hline $\begin{array}{l}\text { Shoot length }(\mathrm{cm}) \\
\text { Shoot circumference }\end{array}$ & $21.47^{\mathrm{a}}$ & $16.23^{\mathrm{b}}$ \\
$(\mathrm{cm})$ & $0.78^{\mathrm{a}}$ & $0.66^{\mathrm{b}}$ \\
Shoot number & $5.17^{\mathrm{a}}$ & $3.17^{\mathrm{b}}$ \\
\hline
\end{tabular}

Figure 1 Representative photographs of (a) wedge-cut scion, (b) scion inserted into the rootstock (scion/stock junction indicated by an arrow), (c) graft treated with sealant and secured with parafilm, and (d) grafted plants inside a screened greenhouse doors.

J. mimosifolia had the largest shoot circumference at 90 days compared with other plants grown in the greenhouse (Fig. 5A). A small variance in shoot circumference was observed among plants grown outdoors. J. mimosifolia, $H$. heptaphyllus, and S. macrophylla showed the largest shoot circumference (Fig. 5B).

Shoot circumference at 90 days after PBZ application was significantly influenced by the growing environment, as also observed at 50 days post-treatment. This parameter was higher $(P \leq 0.05)$ in all plants grown in the greenhouse than in those grown outdoors, except for C. legalis and H. courbaril. The shoot circumference of these species did not differ between environments (Fig. 6).

\section{Reproductive parameters}

J. mimosifolia and S. terebinthifolius responded positively to flowering induction by PBZ (Fig. 7 and 8). At 50 days after PBZ application, J. mimosifolia plants grown outdoors and $S$. terebinthifolius grown in the greenhouse

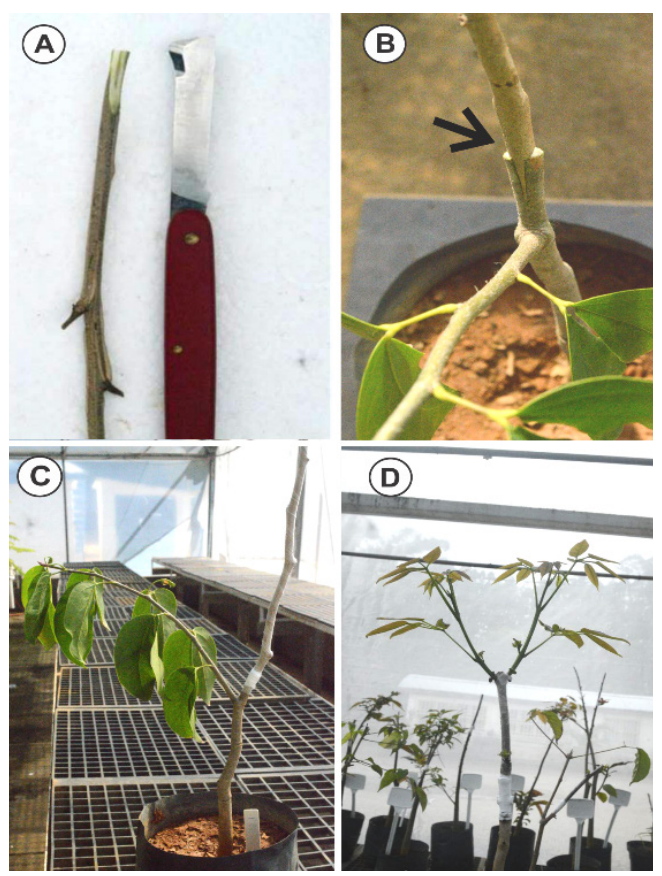



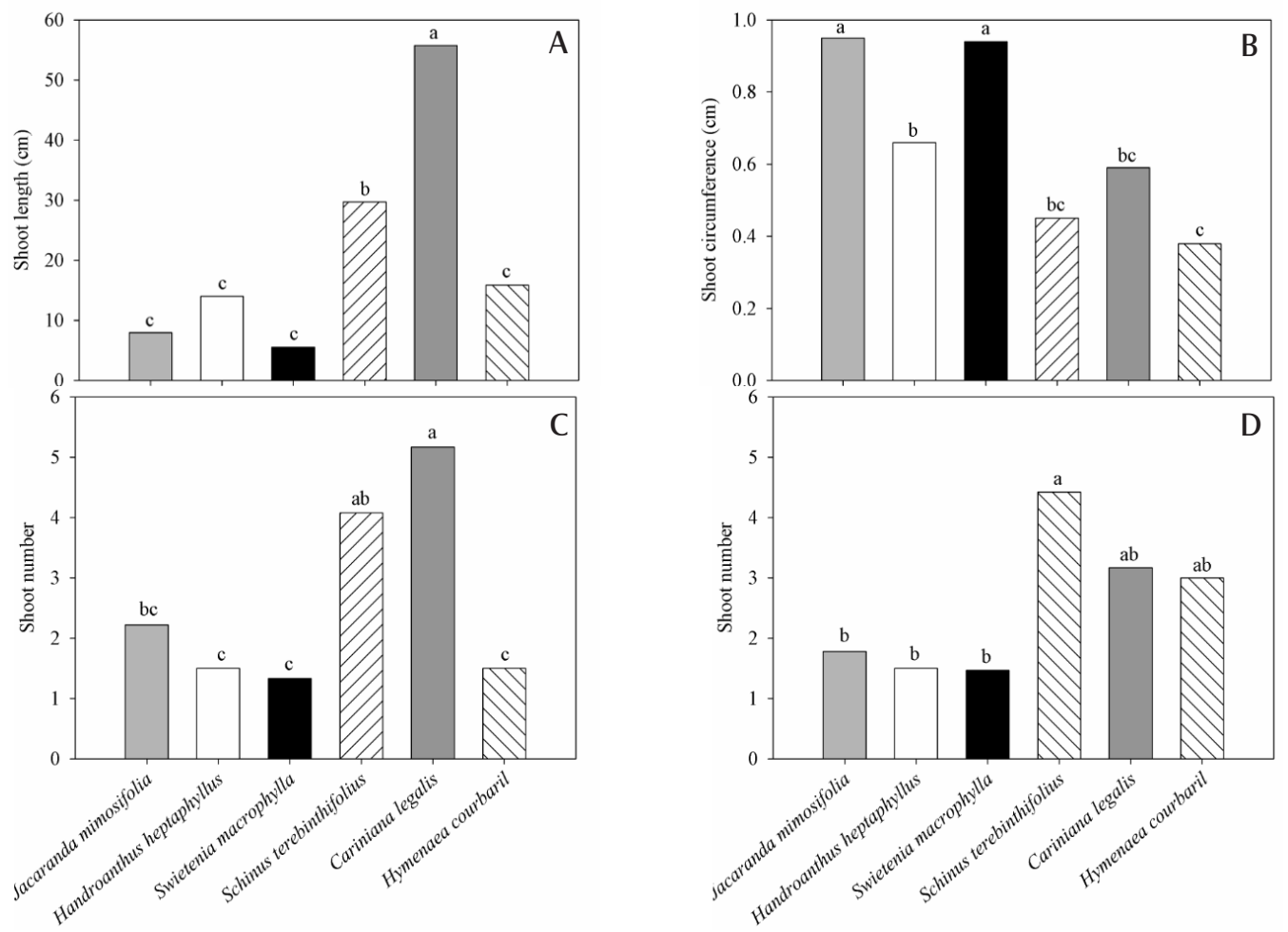

Figure 2 Shoot length (A), shoot circumference (B), shoot number of grafted seedlings grown under greenhouse (C) and outdoor (D) conditions of grafted seedlings at 50 days after application of paclobutrazol. Different letters indicate significant differences at $P \leq 0.05$ by Tukey's test.
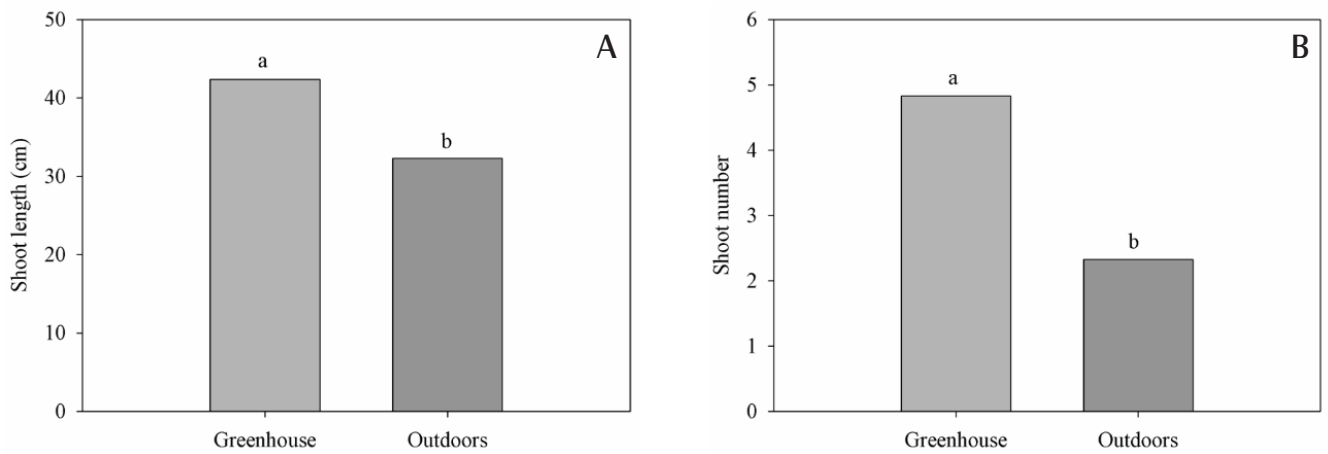

Figure 3 Shoot length (A) and shoot number (B) of Brazilian tree seedlings grown in a greenhouse and outdoors for 90 days after PBZ application. Different letters indicate significant differences at $P$ $\leq 0.05$ by Tukey's test.

showed the largest number of flowers (Fig. 9A). S. terebinthifolius was the only plant with fruits at 50 days after PBZ application. The number of fruits was significantly higher in seedlings grown outdoors than in those grown in the greenhouse (Fig. 9B). 

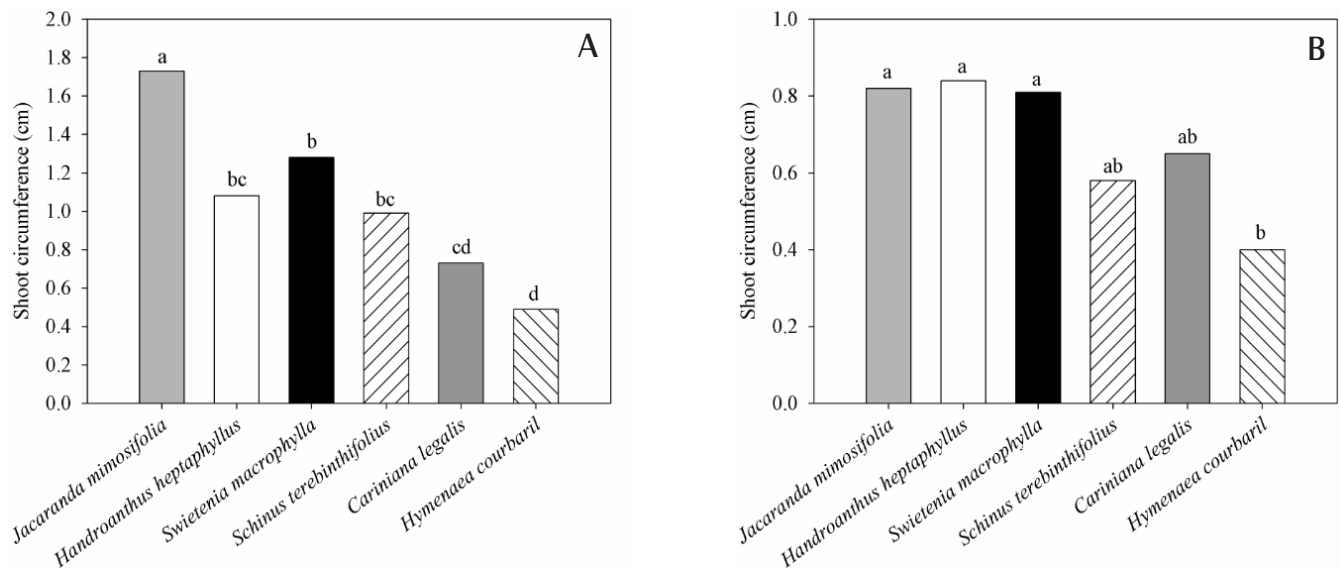

Figure 4 Shoot circumference of Brazilian tree seedlings grown under greenhouse (A) and outdoor (B) conditions for 90 days after PBZ application. Different letters indicate significant differences at $P \leq 0.05$ by Tukey's test.

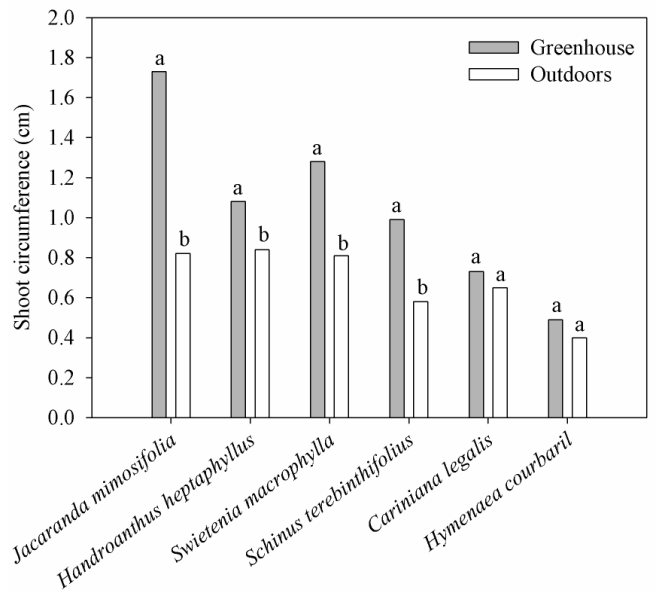

Figure 5 Shoot circumference of Brazilian tree seedlings grown under greenhouse and outdoor conditions for 90 days after paclobutrazol application. Different letters indicate significant differences at $P \leq$ 0.05 by Tukey's test.

At 90 days after PBZ application, only $S$. terebinthifolius seedlings were flowering. The number of flowers was higher in seedlings grown in the greenhouse (Fig. 10A). J. mimosifolia produced fruits when grown under outdoors conditions, and $S$. terebinthifolius pro-duced fruits in both environments (Fig. 10B).
The fruit yield of $S$. terebinthifolius was slightly higher under greenhouse conditions (Fig. 10B).

\section{Discussion}

The improved vegetative development observed in greenhouse plants may be due to their enhanced nutritional status; under greenhouse conditions, soils are not exposed to rain and are less prone to nutrient leaching (Souza et al. 2012).

Other factors known to affect plant growth are a potent inhibitor of GA synthesis. It acts as an antagonist of ent-kaurene oxidase, an enzyme that catalyzes the oxidation of ent-kaurene to ent-kaurenoic acid. By inhibiting GA synthesis, PBZ leads to reduced shoot height and leaf length but increased shoot and leaf diameters (Wang et al. 2019, Xia et al. 2018). Chlorophyll content (Wang et al. 2019) and stomatal conductance (Xia et al. 2018) are improved by PBZ treatment, which in turn enhances photosynthetic performance and carbon uptake. In this study, PBZ application may have increased the photosynthetic rate of plants, as previously reported in Citrul- 

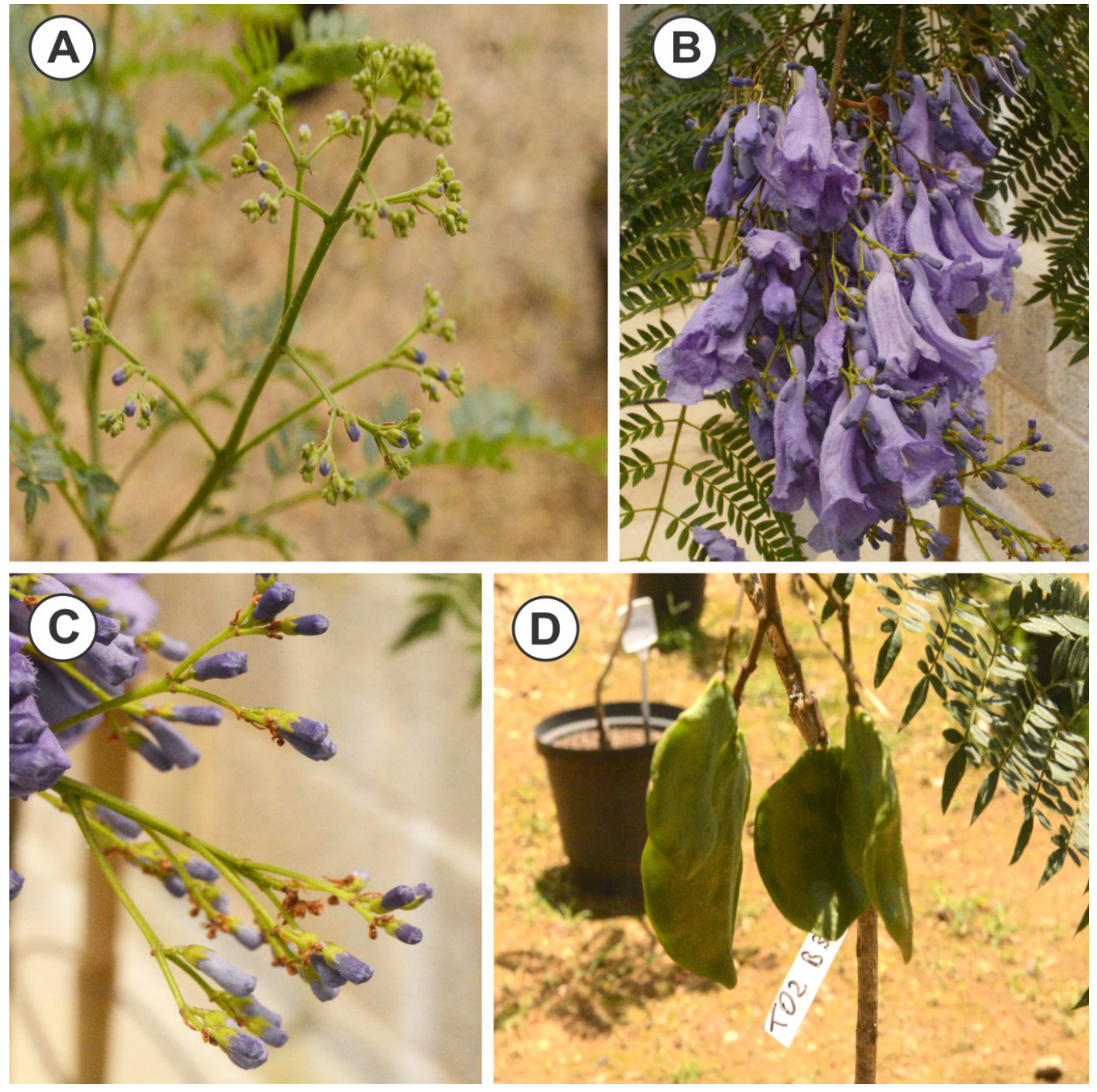

Figure 6 Shoot length (A), shoot circumference (B), shoot number of grafted seedlings grown under greenhouse (C) and outdoor (D) conditions of grafted seedlings at 50 days after application of paclobutrazol. Different letters indicate significant differences at $P \leq 0.05$ by Tukey's test.

luslanatus (Baninasab 2009), Cucumissativus (Baninasab \& Ghobadi 2011), and Punicagranatum (Moradi et al. 2016). PBZ-treated Stevia rebaudiana exhibited enhanced tolerance to biotic and abiotic stresses as well asincreased concentrations of photosynthetic metabolites, carbohydrates, and antioxidant compounds (Hajihashemi 2018). Root biomass responds positively to PBZ (Tanis et al. 2015, Abod
\& Aminor 2000), indicating that this plant growth regulator also contributes to water and nutrient uptake.

The success of breeding programs for genetic conservation of native tree species depends on the development of artificial breeding strategies that reduce the number of inbred progenies and the loss of diversity through genetic drift (Higa \& Silva 2006). Flowering induc- 

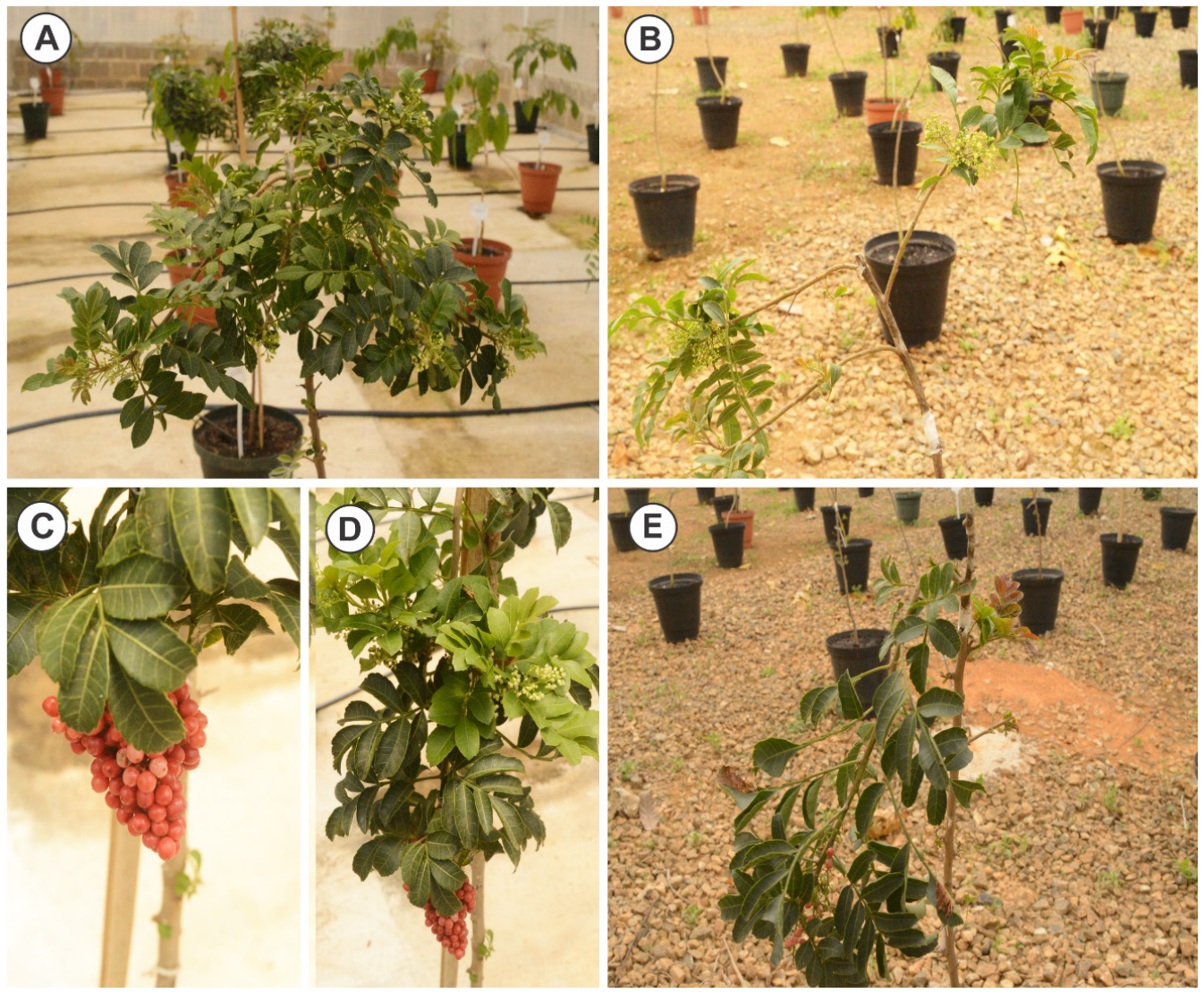

Figure 7 Schinus terebinthifolius plants treated with paclobutrazol showing inflorescences and fruits of plants grown in a greenhouse $(\mathrm{A}, \mathrm{C}$, and $\mathrm{D})$ and outdoors $(\mathrm{B}$ and $\mathrm{E})$

tion is widely used in breeding strategies for selection of superior and diverse genotypes. PBZ application proved to be efficient in stimulating flower bud formation and reducing the time to flowering and fruitingin J. mimosifolia and $S$. terebinthifolius. These effects are of great importance in breeding programs for slow-growth, long-lived trees.

$S$. terebinthifolius and C. legalis show a shoot length, and shoot number significantly higher under greenhouse and outdoor condition when compared with other species. This behaviour can be attributed to the species's characteristics. Considering that $C$. legalis, according to the classification of Budowski (1965), is a late secondary species that toler- ates shade in the seedling stage and becomes an emerging tree as an adult (Costa et al., 2019, Sanches et al., 2010). And S. terebinthifolius has several leaf anatomical aspects found in xerophytes. The multiple layers of the epidermis in the leaf adaxial face protected or mesophilic from excessive desiccation, as well as the presence of a cuticle thick (Azevedo et al. 2015), as occurs in other species of semi-arid environments (Dickson 2000). The presence of stomata in large amount is also a resource shared by most plants in dry environments, and examples are of $M$. urundeuva (Silva et al. 2011) and Agave sisalana (Cunha Neto \& Martins 2012). According to Dickison (2000), as leaves of these plants often used in 

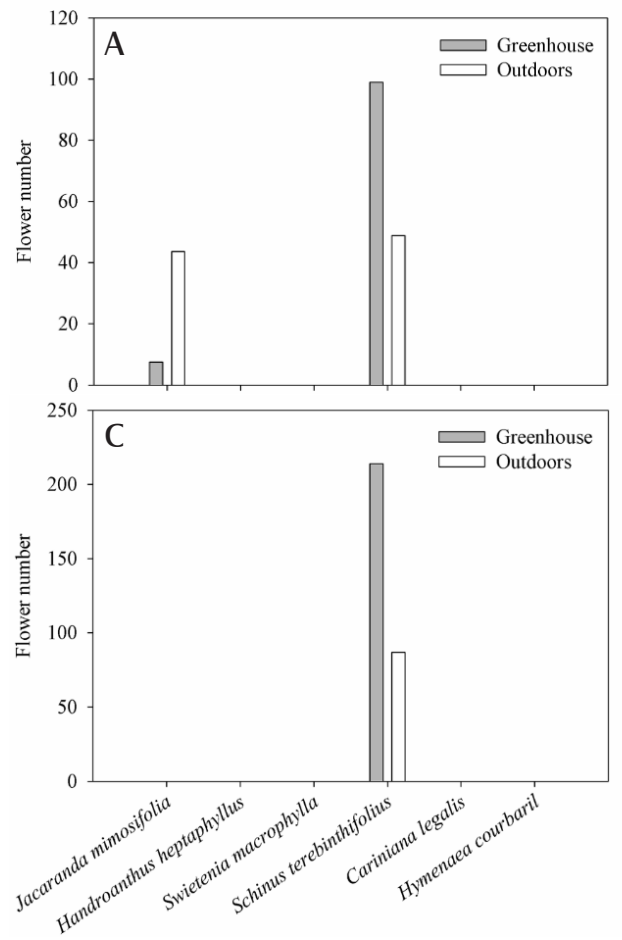
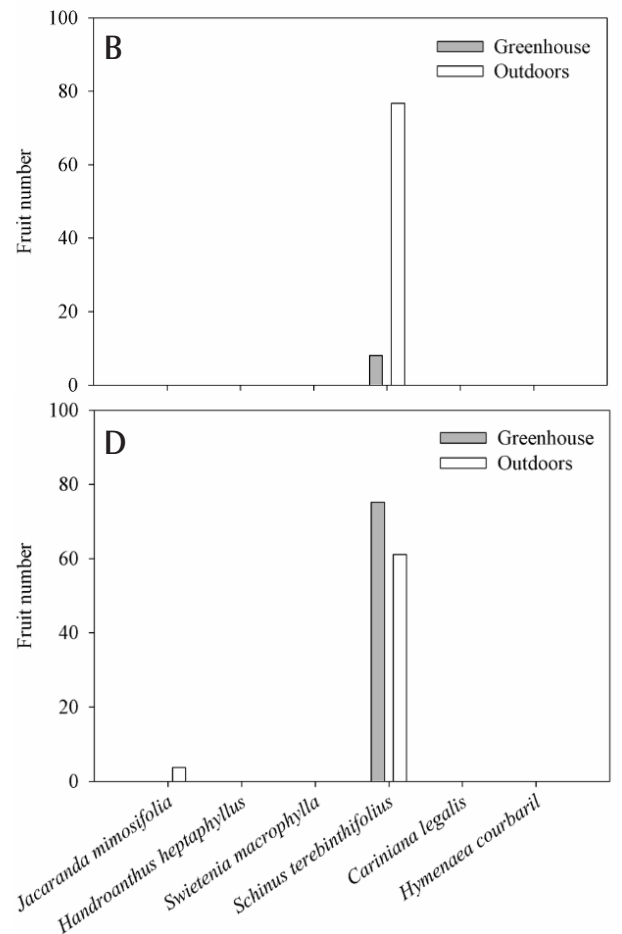

Figure 8 Number of flowers (A, C) and fruits (B, D) of Brazilian tree species at 50 and 90 days after paclobutrazol application, respectively

quite abigger number types of plants than other types of plants are due to the need to control sweating. Besides that, in most species, phloem is facing the abaxial face and the xylem is facing to the adaxial face in the vascular bundle of the rib central, in continuity with these tissues in the stem (Esau 1998). However, in $S$. terebinthifolius, the xylem is arranged radially toaxis, and the phloem is also arranged radially (Azevedo et al. 2015). Giving species an advantage to tolerate and thrive under adverses conditions. Following the same reasoning, $J$. mimosifolius and S. macrophylla presented the higher circumferences. This behaviour can be attributed to the evolutionary characteristics of these species. One is a pioneer and the other is secondary, respectively. Therefore, their growth potential in the shortest time is greater, as they have a more robust root system. Thus, justifying or increasing the circumference of the aerial part.

$S$. terebinthifoliusand J. mimosifolia produced flowers and fruits both outdoors and in the greenhouse, indicating that climatic conditions were favorable for the reproduction of these species. PBZ probably contributed to these results by decreasing GA concentrations (Zhang et al. 2019) and increasing abscisic acid and cytokine concentrations in flower buds (Srivastav et al. 2010, Gardner et al. 2016), thereby redirecting the available resources to flower development (Yuceeret al. 2003, Upreti et al. 2014, Srilatha et al. 2016).

The high number of flowers observed in $S$. terebinthifolius plants grown under greenhouse conditions may be due to the high ambient temperature (Cesário \& Gaglianone 2008). Fruit number was higher in $S$. terebinthifolius plants grown outdoors at 50 days after PBZ application, possibly because of a fast initial 
response to the growth regulator. Such differences were not observed at 90 days after PBZ treatment. Different from $S$. terebinthifolius, $J$. mimosifolia produced a greater number of flowers and fruits under outdoor conditions, confirming the preference of the species for mild temperatures (Carón et al. 2018). J. mimosifolia trees bloom when the temperature is between 20 and $30{ }^{\circ} \mathrm{C}$ and the relative humidity is about $70 \%$ (Sun et al. 2013). The lack of fruiting in J. mimosifoliagrown in the greenhouse may be due to late-acting self-incompatibility. J. mimosifolia flowers are protandrous to prevent self-pollination (Alves et al. 2012); that is, their anthers open before the stigma is receptive (Bittencourt \& Semir 2006, Yanagizawa \& Maimoni-Rodella 2007, Guimarães et al. 2008). J. mimosifoliais preferably pollinated by medium- and large-sized bees (Bittencourt \& Semir 2006, Guimarães et al. 2008), and the enclosed environment of the greenhouse probably limited visitation by these natural pollinators.

In this study, we found that PBZ application induced early flowering and fruiting, in agreement with its effects on grafted Eucalyptus nitens (Gardner et al. 2013), E. smithii (Gardner et al. 2016), E. globulus (Hasan \& Reid 1995), E. camaldulensis, and E. tereticornis (Varghese et al. 2009) seedlings, confirming the efficacy of this growth regulator in accelerating the transition to adulthood in perennial tree species.

Excepting $S$. terebinthifolius and J. mimosifolia, the other tree species analyzed in this study did not flower. This can be attributed to the following factors: (i) existence of interspecific differences in susceptibility to flowering induction (Gardner et al. 2016), (ii) use of insufficient PBZ co ncentrations (Yuceer et al. 2003), (iii) inadequate timing of PBZ application (Sarker \& Rahim 2012, Martínez-Fuentes et al. 2013), (iv) transfer of juvenile hormones from the rootstock to the scion (Gardner et al. 2016), and (v) seedling immaturity, as observed in Populus deltoides (Yuceer et al. 2003) and E. nitens (Gardner et al. 2013). Wil48 liams et al. (1999), studying the effect of PBZ on E. nitens flowering, found that the plants have high levels of reproductive inhibitors and few individuals can be induced to flower early, indicating that a complex set of conditions must be met for the onset of reproductive development. Thus, the phenological differences observed between the six native tree species after PBZ application and cultivation under greenhouse and outdoor conditions may be of physiological origin.

Clonal seed orchards can produce seeds with wide genetic variability for reforestation and ecosystem restoration programs. For genetic conservation programs, it is important to maintain as many alleles as possible and maximize the degree of genetic dissimilarity by crossing. This strategy can reduce the negative effects of inbreeding and genetic drift (El-Kassaby et al. 2019). An effective population size of 175 to 200 (Resende 2002) is preferred and should be obtained by crossing dissimilar individuals. Genetic dissimilarity can be promoted by introducing pollen from other populations.

\section{Conclusion}

Shoot number, length, and circumference were greater in plants grown under greenhouse conditions. The vegetative developments of $S$. terebinthifolius and $C$. legalisare superior to the rest of the species studied under cultivation conditions. The combined use of grafting and PBZ application was effective in inducing early flowering in J. mimosifolia and S. terebinthifolius, an important advance for the conservation and genetic improvement of these species. This method can allow the production of seeds with good genetic value from full-sib progeny tests, genetic rescue of plants at risk of extinction, and rescue of trees damaged by environmental accidents. Further studies can be carried out to hybridize $J$. mimosifolia and S. terebinthifolius with related species for the production of interspecific, heterotic hybrids. 


\section{Acknowledgments}

The authors would like to thank the Universidade Federal de Viçosa, the Sociedade de Investigações Florestais (SIF) and Brazilian fund agencies Coordenação de Aperfeiçoamento de Pessoal de Nível Superior (CAPES) and Conselho Nacional de Desenvolvimento Científico e Tecnológico (CNPq) for their support to this research project.This study was financed in partbythe Coordenação de Aperfeiçoamento de Pessoal de Nível Superior - Brasil (CAPES) - FinanceCode 001.

\section{References}

Abod S.A., Aminor A., 2000. Effects of paclobutrazol on the growth of seedlings of two dipterocarp species. Journal of Tropical Forest Science 12: 503-508.

Alves G.R., Peruchi A., Agostini K., 2012. Polinização em área urbana: o estudo de caso de Jacaranda mimosifolia D. Don (Bignoniaceae) [Pollination in anurbanarea: the Jacaranda mimosifolia D. Don (Bignoniaceae) case study]. Bioikos 24: 31-41.

Assis T.F., Mafia R.G., 2007. Hibridação e Clonagem. In: Borém A (ed.), Biotecnologia florestal. Visconde do Rio Branco, MG: Suprema Gráfica e Editora Ltda. 1: 93-121.

Assis T.F., Warburton P., Harwood C., 2005. Artificially induced protogyny: an advance in the controlled pollination of Eucalyptus. Australian Forestry 68: 27-33. DOI: 10.1080/00049158.2005.10676223

Azevedo C.F., Quirino Z.G.M., Bruno R.L.A., 2015. Estudo farmacobotânico de partes aéreas vegetativas de aroeira-vermelha (Schinus terebinthifolius Raddi, Anacardiaceae) [Pharmaco-botanical study of the aerial parts of Brazilian pepper (Schinus terebinthifolius Raddi).]. Revista brasileira de plantas medicinais 17: 26-35. DOI: 10.1590/1983-084X/11_090

Balestrin D., Martins S.V., Schoorl J.M., Lopes A.T., Andrade C.F., 2019. Phytosociological study to define restoration measures in a mined area in Minas Gerais, Brazil. Ecological Engineering 135: 8-16. DOI: 10.1016/j. ecoleng.2019.04.023

Baninasab B., 2009 Amelioration of chilling stress by paclobutrazol in watermelon seedlings. Scientia Horticulturae 121: 144-148. DOI: 10.1016/j.scienta.2009.01.028

Baninasab B., Ghobadi C., 2011 Influence of paclobutrazol and application methods on high-temperature stress injury in cucumber seedlings. Journal of Plant Growth Regulation 30: 213-219. DOI: 10.1007/s00344-0109188-2
Barth C., Tullio M., Conklin P.L., 2006. The role of ascorbic acid in the control of flowering time and the onset of senescence. Journal of Experimental Botany 57:16571665. DOI: $10.1093 / \mathrm{jxb} / \mathrm{erj} 198$

Bhering L.L., 2017. Rbio: A tool for biometric and statistical analysis using the $\mathrm{R}$ platform. Crop Breeding and Applied Biotechnology 17: 187-190. DOI: 10.1590/1984-70332017v17n2s29

Bindu G.V., Upreti K.K., Sathisha G.J., 2018. Effects of paclobutrazol on non-enzymatic and enzymatic antioxidants during floral bud development in mango (Mangifera indica L.) cv. Totapuri. International Journal of Current Microbiology and Applied Sciences 7: 16081617. DOI: $10.20546 /$ ijcmas.2018.701.195

Bittencourt N.S., Semir J., 2006 Floral biology and late-acting self-incompatibility in Jacaranda racemosa (Bignoniaceae). Australian Journal of Botany 54: 315324. DOI: 10.1071/BT04221

Budowski G., 1965. Distribution of tropical American rain-forest species in the light of successional processes (No. 10254).

Carón M.M., Frenne P., Ortega-Baes P., Quinteros A., Verheyen K., 2018. Regeneration responses to climate and land-use change of four subtropical tree species of the southern Central Andes. Forest Ecology and Management 417: 110-121. DOI: 10.1016/j.foreco.2018.02.006

Cesário L.F., Gaglianone M.C., 2008 Biologia floral e fenologia reprodutiva de Schinus terebinthifolius Raddi (Anacardiaceae) em Restinga do Norte Fluminense [Floral biology and reproductive phenology of Schinus terebinthifolius Raddi (Anacardiaceae) in the restinga of northern Rio de Janeiro State]. Acta Botanica Brasilica 22: 828-833. DOI: 10.1590/S010233062008000300018

Costa G.S., Dalmolin Â.C., Schilling A.C., Sanches M.C., Santos M.S., Mielke M.S., 2019. Physiological and growth strategies of two Cariniana species in response to contrasting light availability. Flora 258: 151427. DOI: $10.1016 /$ j.flora.2019.151427

Cruz C.D., 2013. Genes: a software package for analysis in experimental statistics and quantitative genetics. Acta Scientiarum, Agronomy 35: 271-276. DOI: 10.4025/actasciagron.v35i3.21251

Cunha Neto I.L., Martins F.M., 2012. Anatomia dos órgãos vegetativos de Agave sisalana Perrine ex Engelm (Agavaceae) [Anatomy of the vegetative organs of Agave sisalana Perrine ex Engelm (Agavaceae)]. Revista Caatinga 25: 72-78.

Dickinson G.R., Wallace H.M., Lee D.J., 2010. Controlled pollination methods for creating Corymbia hybrids. Silvae Genetica 59: 233-241. DOI: 10.1515/sg-2010-0028

Dickison W.C., 2000. Integrative Plant Anatomy. Academic Press, San Diego, 533 p.

Domingos O.D.S., Alcântara B.G., Santos M.F., Maiolini T., Dias D.F., Baldim J. L., Lago J.H.G., Soares M.G., Chagas-Paula D. A., 2019. Anti-inflammatory derivatives with dual mechanism of action from the metabolomic screening of Poincianella pluviosa. Molecules 24: 
4375. DOI: $10.3390 /$ molecules 24234375

El-Kassaby Y.A., Wang Q., Wang T., Ratcliffe B., Bi Q.X., Wang Z., Mao J.-F., Guan W., 2019. Concept for gene conservation strategy for the endangered Chinese yellowhorn, Xanthoceras sorbifolium, based on simulation of pairwise kinship coefficients. Forest Ecology and Management 432: 976-982. DOI: 10.1016/j.foreco.2018.10.045

Esau K., 1998. Anatomia das plantas com sementes [Anatomy of plants with seeds]. Edgard Blücher, São Paulo, 296 p.

Farias C.P., Alves G.S., Oliveira D.C., Melo E.I., Azevedo L.C.B., 2020. A consortium of fungal isolates and biochar improved the phytoremediation potential of Jacaranda mimosifolia $\mathrm{D}$. Don and reduced copper, manganese, and zinc leaching. Journal of Soils and Sediments 20: 260-271. DOI: 10.1007/s11368-019-02414-3

Gardner R.A., Bertling I., Savage M.J., 2013. Overhead irrigation increased winter chilling and floral bud production in Eucalyptus nitens. Southern Forests 75: 199212. DOI: $10.2989 / 20702620.2013 .858209$

Gardner R.A.W., Bertling I., Savage M.J., Naidoo S., 2016. Investigating optimal site conditions for flower bud production in Eucalyptus smithii orchards in South Africa. Australian Forestry 79: 137-146. DOI: 10.1080/00049158.2016.1159164

Guimarães E., Di Stasi L.C., Maimoni-Rodella R. de C.S., 2008. Pollination biology of Jacaranda oxyphylla with an emphasis on staminode function. Annals of Botany 102: 699-711. DOI: 10.1093/aob/mcn 152

Hajihashemi S., 2018. Physiological, biochemical, antioxidant and growth characterizations of gibberellin and paclobutrazol-treated sweet leaf (Stevia rebaudiana B.) herb. Journal of Plant Biochemistry and Biotechnology 27: 237-240. DOI: $10.1007 / \mathrm{s} 13562-017-0428-4$

Hamzah S., Chan J.L., Yeang H.Y., 2002. Pollen tube growth and fruit-set success in Hevea brasiliensis hand-pollination influenced by the choice of clone and female flower. Euphytica 123: 1-8. DOI: 10.1023/A: 1014486004608

Hasan O., Reid J.B., 1995. Reduction of generation time in Eucalyptus globulus. Plant Growth Regulation 17: 53-60.

Higa A.R., Silva L.D., 2006. Pomar de Sementes de Espécies Florestais Nativas [Orchard of seeds of native forest species]. Curitiba: FUPEF, $264 \mathrm{p}$.

Horsley T.N., Johnson S.D., Myburg A.A., 2010. Comparison of different control-pollination techniques for small-flowered eucalypts. New Forests 39: 75-88. DOI: 10.1007/s11056-009-9156-5

Kishore K., Singh H.S., Kurian R.M., 2015. Paclobutrazol use in perennial fruit crops and its residual effects: A review. Indian Journal of Agricultural Sciences 85: 863-872.

Lisboa D.O., Silva M.A., Machado A.R., Pinho D.B., Borges L.S., Pereira O.L., Furtado G.Q., 2016. First report of botryosphaeriaceous fungi causing canker on Cedrela fissilis and leaf spots on Cariniana estrellensis in forest nursery in Brazil. Forest Pathology 46: 362365. DOI: $10.1111 /$ efp.12281

Ma Y.Q., Liu M.H., Jiang K., Guo .L, Qu S.J., Wan Y.Q., Tan C.H., 2018. Limonoids from the fruits of Swietenia macrophylla with inhibitory activity against $\mathrm{H} 2 \mathrm{O} 2$-induced apoptosis in HUVECs. Fitoterapia 129: 179-184. DOI: 10.1016/j.fitote.2018.07.001

Martínez-Fuentes A., Mesejo C., Muñoz-Fambuena N., Reig C., González-Mas M.C., Iglesias D.J., Primo-Milo E., Agustí M., 2013. Fruit load restricts the flowering promotion effect of paclobutrazol in alternate bearing Citrus spp. Scientia Horticulturae 151: 122-127.

Moradi S., Baninasab B., Gholami M., Ghobadi C., 2016. Paclobutrazol application enhances antioxidant enzyme activities in pomegranate plants affected by cold stress. The Journal of Horticultural Science and Biotechnology 92: 65-71. DOI: 10.1080/14620316.2016.1224605

Moran G.F., Bell J.C., 1983. Eucalyptus. In: Tanksley S.D., Orton T. (eds.), Isozymes in plant gewnetics and breeding, 1B: 423-441. DOI: 10.1016/B978-0-44442227-9.50024-X

Oliveira A.F.D., Neves C.L.P., Pereira G.D.A., Garcia F.H.S., Coelho S.J., Pereira J.A.A. 2018. Floristics of road forestry conflicting with the electrical networks: a case study in the southern region of Minas Gerais State. Ornamental Horticulture 24: 277-284. DOI: 10.14295/ oh.v24i3.1239

Potts B.M., McGowen M.H., Williams D.R., Suitor S., Jones T.H., Gore P. L., Vaillancourt R.E. 2008. Advances in reproductive biology and seed production systems of Eucalyptus: the case of Eucalyptus globulus. Southern Forests: a Journal of Forest Science 70(2): 145-154. DOI: 10.2989/SOUTH.FOR.2008.70.2.10.538

Potts B.M., Potts W.C., Cauvin B., 1987. Inbreeding and interspecific hybridization in Eucalyptus gunnii. Silvae Genetica 36: 194-199.

Randall B.W., Walton D.A., Lee D.J., Wallace H.M., 2015. Comparison of three pollination methods for Eucalyptus argophloia, a small-flowered eucalypt. Annals of Forest Science 72: 127-133. DOI: 10.1007/s13595014-0407-z

Sanches M.C., Ribeiro S.P., Dalvi V.C., Silva Junior M.B., Sousa H.C., Lemos-Filho J.P., 2010. Differential leaf traits of a neotropical tree Cariniana legalis (Mart.) Kuntze (Lecythidaceae): comparing saplings and emergent trees. Trees 24: 79-88. DOI: 10.1007/s00468-0090380-6

Sarker B.C., Rahim M.A., 2012. Vegetative growth, harvesting time, yield and quality of mango (Mangifera indica L.) as influenced by soil drench application of paclobutrazol. Bangladesh Journal of Agricultural Research 37: 335-348. DOI: 10.3329/bjar.v37i2.11238

Silva A.B., Silva T., Franco E.S., Rabelo S.A., Lima E.R., Mota R.A., Lima-Filho, J.V., 2010. Antibacterial activity, chemical composition, and cytotoxicity of leaf's essential oil from Brazilian pepper tree (Schinus terebinthifolius, Raddi). Brazilian Journal of Microbiology 41: 158-163. DOI: 10.1590/S1517-83822010000100023 
Silva O.N., Leite D.B. de S., Bernardes L.A., 2011. Morphology, anatomy and histochemistry of the leaves of Myracrodruon urundeuva Allemão (Anacardiaceae). Boletín Latinoamericano y del Caribe de Plantas Medicinales y Aromáticas 10: 56-66.

Silva P.H.M., Moraes C.B.D., Mori E.S., 2012 Polinização controlada em eucaliptos nas empresas florestais brasileiras [Controlled pollination in eucalyptus in Brazilian forestry companies]. Circular Técnica IPEF 204:112.

Soumya P.R., Kumar P., Pal M., 2017. Paclobutrazol: a novel plant growth regulator and multi-stress ameliorant. Indian Journal of Plant Physiology 22: 267-278. DOI: $10.1007 / \mathrm{s} 40502-017-0316-x$

Souza M.S.P.A., Santos F.S., Magalhães L.M.S., Freitas W.K., Gois G., Oliveira Júnior J.F., 2019. Poincianella pluviosa as biomonitor of heavy metals in the municipality of Volta Redonda, RJ, Brazil. Revista Brasileira de Engenharia Agrícola e Ambiental 23: 71-76. DOI: 10.1590/1807-1929/agriambi.v23n1p71-76

Souza T.R.D., Villas Boas R.L., Quaggio J.A., Salomão L.C., Foratto L.C., 2012. Dinâmica de nutrientes na solução do solo em pomar fertirrigado de citros [Nutrient dynamics in soilsolution in a fertigated citrus orchard]. Pesquisa Agropecuária Brasileira 47:846-854. DOI: 10.1590/S0100-204X2012000600016

Srilatha V., Reddy Y.T.N., Upreti K.K., Venugopalan R., Jayaram H.L., 2016. Responses of pruning and paclobutrazol in mango (Mangifera indica L.): changes in tree vigour, flowering and phenols. Journal of Applied Horticulture 18: 148-153.

Srivastav M., Kishor A., Dahuja A., Sharma R.R., 2010. Effect of paclobutrazol and salinity on ion leakage, proline content and activities of antioxidant enzymes in mango (Mangifera indica L.). Scientia Horticulturae 125: 785-788. DOI: 10.1016/j.scienta.2010.05.023

Sun Y., Li F., Shi J.A., 2013. Study on test materials with the relationship between growth and development characteristics and temperature and relative humidity of Jacaranda mimosifolia. Advanced Materials Research 743: 189-194. DOI: 10.4028/www.scientific.net/ AMR.743.189

Tanis S.R., McCullough D.G., Cregg B.M., 2015. Effects of paclobutrazol and fertilizer on the physiology, growth and biomass allocation of three Fraxinus species. Urban Forestry \& Urban Greening 14: 590-598. DOI: 10.1016/j.ufug.2015.05.011

Upreti K.K., Prasad S.S., Reddy Y.T.N., Rajeshwara A.N., 2014. Paclobutrazol induced changes in carbohydrates and some associated enzymes during floral initiation in mango (Mangifera indica L.) cv. Totapuri. Indian Journal of Plant Physiology 19: 317-323. DOI: 10.1007/ s40502-014-0113-8

Varghese M., Ravi N., Kamalakannan R., Harwood C.E., 2009. Effect of silvicultural treatments on growth, fertility and capsule traits in seedling seed orchards of Eucalyptus camaldulensis and E. tereticornis. New Forests 37: 99-107. DOI: 10.1007/s11056-008-9111-x

Veggi P.C., Prado J.M., Bataglion G.A., Eberlin M.N., Meireles M.A.A., 2014. Obtaining phenolic compounds from jatoba (Hymenaea courbaril L.) bark by supercritical fluid extraction. The Journal of Supercritical Fluids 89: 68-77. DOI: 10.1016/j.supflu.2014.02.016

Wang H., Shen W., Guo J., Wang C., Zhao Z. 2019. Regulating growth of Betula alnoides Buch. Ham. ex D. Don seedlings with combined application of paclobutrazol and gibberellin. Forests 10: 378-389. DOI: 10.3390/ f10050378

Wei X.J., Ma J., Wang K., Liang X.J., Lan J.X., Li Y.J., Li K.X., Liang H. 2018. Early flowering induction in golden Camellia seedlings and effects of paclobutrazol. HortScience 53(12): 1849-1854. DOI: 10.21273/ HORTSCI13676-18

Xia X., Tang Y., Wei M., Zhao D., 2018. Effect of paclobutrazol application on plant photosynthetic performance and leaf greenness of herbaceous peony. Horticulturae 4: 5-16. DOI: 10.3390/horticulturae4010005

Yanagizawa Y.A., Maimoni-Rodella R.C.S., 2007. Floral visitors and reproductive strategies in five melittophilous species of Bignoniaceae in Southeastern Brazil. Brazilian Archives of Biology and Technology 50: 1043-1050. DOI: 10.1590/S1516-89132007000700015

Yuceer C., Kubiske M.E., Harkess R.L., Land Junior S.B., 2003. Effects of induction treatments on flowering in Populus deltoides. Tree Physiology 23: 489-495. DOI: 10.1093/treephys/23.7.489

Zhang Q.Q., Wang J.G., Wang L.Y., Wang J.F., Wang Q., Yu P., Mai M.-Y., Fan M. 2019. Gibberellin repression of axillary bud formation in Arabidopsis by modulation of DELLA-SPL9 complex activity. Journal of Integrative Plant Biology DOI: 10.1111/jipb.12818

Zhang S., Zhang D., Fan S., Du L., Shen Y., Xing L., Li Y., Ma J., Han M. 2016. Effect of exogenous GA3 and its inhibitor paclobutrazol on floral formation, endogenous hormones, and flowering-associated genes in 'Fuji' apple (Malus domestica Borkh.). Plant Physiology and Biochemistry 107: 178-186. DOI: $10.1016 /$ j. plaphy.2016.06.005 
